FEĐA MILIVOJEVIĆ

UDC: $355.4(381) “-171 /-168 “$

Aleksandera von Humboldta 12

HR-10000 Zagreb

fmilivojevic@gmail.com

\title{
USCANA, PERSEUS AND THE ROMANS: LIVY AND THE CHRONOLOGY OF WAR OPERATIONS IN THE THIRD MACEDONIAN WAR
}

\begin{abstract}
The author is trying to solve the chronological problems of Livy's information on the war operations in the region around and north of Lake Lychnidus during the Third Macedonian War. The focus is on the period between 170-169 B.C., namely, the problems regarding Livy's information on Perseus' counterattack on Roman positions at the turn of 170/169 B.C., Roman control over the city of Uscana and one undocumented Perseus' attack on Dardanians in 170 B.C. The author concludes the events in question have a mutual connection, proposes new chronological course of events and emphasizes the importance of Livy's 43rd book for the study of the consequences of the war operations north of Lake Lychnidus during the Third Macedonian War.
\end{abstract}

Key words: Uscana, Third Macedonian War, Dardanians, Livy, Perseus, Claudius Centho

During the second part of the $20^{\text {th }}$ century modern historiography has dealt in detail about the Third Macedonian War, its course and rather numerous chronological problems of Livy's account of the war. Since the works of N. G. L. Hammond and F. W. Walbank ${ }^{1}$ there has been several significant interpretations of Livy's words and historical reconstructions of certain events. ${ }^{2}$ While the research is indeed extensive and the war operations in Thessaly have been explained in detail, little or no attention has been given to Livy's information concerning the war operations between Romans and Macedonians in the region around and north of Lake Lychnidus. ${ }^{3}$ Several preserved information lead to the assumption that, apart from Thessaly, the region in question was the setting of another front of war operations during the Third Macedonian

${ }^{1}$ Namely Walbank 1941; Hammond 1968; Walbank 1976; Hammond, Walbank 1988; Hammond 1993 etc.

${ }^{2}$ Such as Luce 1977; Warrior 1981; Briscoe 2012 etc.

${ }^{3}$ Lake Lychnidus = today Lake Ohrid. There has been only one work that dealt with this topic directly, yet the conclusions which Nikola Vulić brought are indeed outdated. See Vulić 1934. 
War. However, sporadically written throughout Livy's books those pieces of information are available only through isolated campaigns of Roman commanders who for different reasons engaged in several military campaigns. We do not have a comprehensive story about the war operations, the correlation between campaigns is unclear and often without a tangible chronological connection. Because of that the events around Lake Lychnidus in the Third Macedonian War are disproportionately represented in modern works, opposed to simultaneous events in Thessaly and major skirmishes involving consuls, praetors and a king.

Therefore, in this contribution I will point out several chronological problems of Livy's text and propose possible solutions about the war operations around Lychnidus Lake specifically between 170-169 B.C. The focus will be on analysing the problems regarding: 1) Perseus' counterattack on Roman positions at the turn of 170/169 B.C.; 2) the specific dating of Perseus' counterattack; 3) the dating of Roman control over the city of Uscana; 4) the dating and consequences of one undocumented Perseus' attack in the region that probably happened somewhere during 170 B.C. As a conclusion to this article a detailed overview will be presented which may serve as a base for further discussion.

\section{Background}

In essence the story of the war operations north of Lychnidus is based on the activities of several less known Roman commanders and the king of Macedonia. Precisely: 1) Gnaeus Sicinius; 2) Appius Claudius Centho; 3) Perseus; 4) Lucius Coelius; 5) Lucius Anicius Gallus. ${ }^{4}$ There is no need to explain in detail the course of action of each of these commanders. This article examines only the events at the turn of 170-169 B.C. (commanders 2 and 3) while the region around Lychnidus witnessed Roman-Macedonian conflicts during the whole Third Macedonian War (171-167 B.C.). But due to the fragmented state of Livy's books a brief historical background is necessary. Otherwise Livy's sporadic information on the war operations are quite difficult to follow. It may seems they lack a proper chronological order and interconnection, but the truth is far from it.

First and foremost, as already said, war operations in the region north of Lake Lychnidus are part of probably the largest military conflict during the second century B.C. - the Third Macedonian War (171168 B.C.). The war between Perseus and Rome started as a result of Macedonia's interference in Greek affairs causing Rome's position in the East to become weaker. The Senate declared war against Macedonia

${ }^{4}$ Sicinius: Liv. 42.18; Liv. 42.36.; Zon. $9.22=$ Dio 20. Claudius: Liv. 43.9-10. Perseus: Liv. 43.18-20. Coelius: Liv. 43.21. Anicius: Liv. 44.21, 44.30-32, 45.3. 
at the moment when it was clear that Perseus provided an alternative for the policies of Greek communities (other than them siding with Rome). The Senate reacted swiftly, and the war which Perseus probably tried to avoid was inevitable. ${ }^{5}$ As for the events in the region around Lychnidus, everything started with the activities of praetor Gnaeus Sicinius in 172 B.C. His assignment represented the outbreak of the war operations not only in the region around Lychnidus, but in the whole Third Macedonian War.

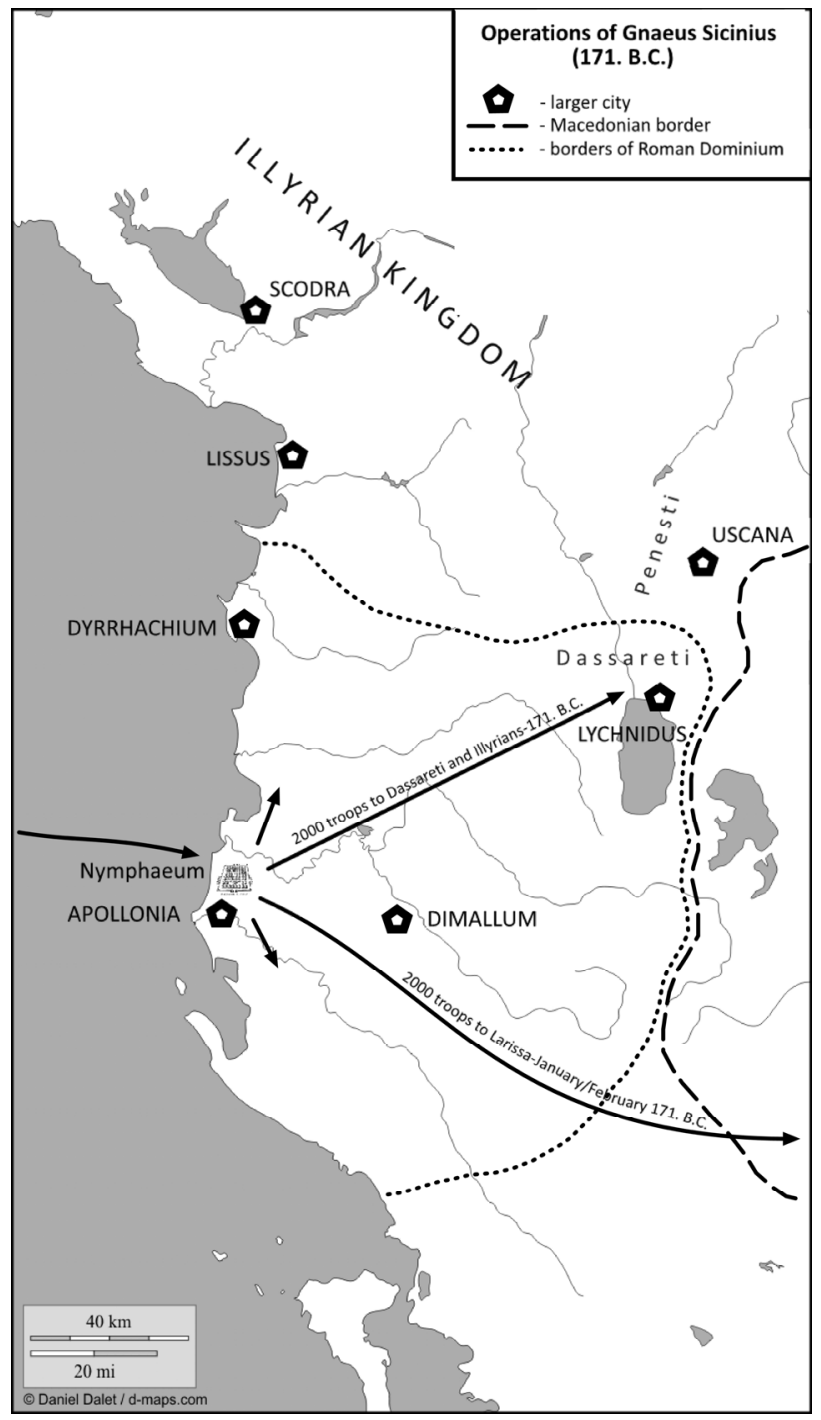

Map 1. Operations of Gnaeus Sicinius

${ }^{5}$ See Hammond 1988, 505 ff. Derow 1989 and cited literature. 
As Livy writes, in the same paragraph where he mentions Rome's declaration of war to Perseus (172 B.C.), considering the preparations for the war against Perseus started, the Senate decided that praetor Gnaeus Sicinius should transfer troops from Brundisium to Apollonia in Epirus. Sicinius was supposed to distribute troops as garrisons in coastal cities where the consul will soon disembark with his own army. ${ }^{6}$ That Sicinius successfully completed his task we find out from Livy's information dated for 171 B.C. Sicinius transferred 5000 infantry and 300 cavalry and raised a camp in the vicinity of Apollonia (at Nymphaeum). What is more, Sicinus sent tribunes with 2000 troops to occupy the forts of the Dassareti and Illyrians, peoples who asked garrisons so they could be better protected from their Macedonian neighbours (see Map 1). ${ }^{7}$

There is no further information on Sicinius' role in the Third Macedonian War. In 170 B.C. we find him again across the Adriatic, this time involved in solving the problem consul Gaius Cassius caused by trying to reach Macedonia through Illyricum. ${ }^{8}$ As for Sicinius' command in 171 B.C., the securing of the coastal belt of modern day Albania is rather clear. The decision to send 2000 troops to the forts of the Dassareti and Illyrians, however, seems isolated and without context, but it is far from coincidental. In his $43^{\text {rd }}$ book Livy writes that a year later from Sicinius' task (170 B.C.) Rome became very suspicious in Genthius, the Illyrian king. ${ }^{9}$ The Senate thought precautionary measures were necessary and decided that the consul in Macedonia, Aulus Hostilius Mancinus, should send Appius Claudius Centho in Illyricum with 4000 troops so he could protect the bordering peoples. Claudius asked from the allies additional troops and with altogether 8000 troops occupied the position in Lychnidus, among the Dassareti. $^{10}$

The correlation between Sicinius' and Claudius' task is rather evident. Sicinius sent 2000 troops as garrisons to the region where, almost a year and a half later, Claudius arrived with his army. The intention of both commanders was to protect the region of great strategic importance - precisely from Lake Lychnidus to the north and the slo-

${ }^{6}$ Liv. 42.18 .

${ }^{7}$ Liv. 42.36.; Zon. 9.22 = Dio 20. Gruen 1984, 227.

${ }^{8}$ Liv. 43.5.10. The problem was with the Carnians, Histrians and Iapodians. Livy writes the cognomen Gaius, but it should be Gnaeus. See Broughton 1951, 423 n. 7; Gruen 1984, 227.

${ }^{9}$ Liv. 43.9. Rome was suspicious of Genthius' behaviour even before. For the report of the Issaean embassy (172 B.C.) see Liv. 42.26. Also Genthius was the only king on the Eastern shores of the Adriatic still hesitant to join either side in the Third Macedonian War. See Liv. 42.29: Genthius rex Illyriorum fecerat potius cur suspectus esset Romanis quam satis statuerat, utram foveret partem impetuque magis quam consilio his aut illis se adiuncturus videbatur. For the embassy of L. Decimius to Genthius' court (172 B.C.) see: Liv. 42.37.1-2.

${ }^{10}$ Liv. 43.9. 
pes of Sharr Mountain. ${ }^{11}$ But Claudius also had other plans. Livy extensively writes that not long after he chose Lychnidus as his center of operations (autumn of 170 B.C.), Claudius attacked Uscana, the biggest city of the Penesti. ${ }^{12}$ At that time, Uscana was part of Perseus' territory and had a Macedonian garrison (a small detachment of Cretan soldiers). Claudius received reports that the inhabitants would rise against the Macedonians if he were to attack the city. Therefore, Claudius launched an attack during the night, but a sudden onslaught from the city completely shattered his army. During the retreat more soldiers were lost than in the attack, and he returned to Lychnidus with only 2000 troops (see Map 2). ${ }^{13}$

News of Claudius' defeat reached the Senate through a military tribune Sextus Digitus. Because of these disturbing news, and in general because of a bad conduct of the war against Perseus, envoys Marcus Fulvius Flaccus and Marcus Caninius Rebilus were sent to investigate in what state was the consuls army in Thessaly, and to find out what exactly happened at Uscana. At the end of February the envoys returned to Rome, and the contents of their report are partially known. The Senate was not so benevolent towards Claudius or the envoys. The reason was the envoys' statement that very few Italian soldiers fell in the attack, and that most of them were allies. According to the Senate such description of the attack was diminishing Claudius' shameful defeat, whether it was true or not. ${ }^{14}$

Livy's report ends here and we do not have information what occurred with Claudius after the retreat. His defeat was a major upset for the Roman cause in the region which proved tough to control. Based on what Livy writes, the defeat had quite an impact on Claudius.

${ }^{11}$ For Sharr Mountain: Liv. 43.20.1; Polyb. 28.8.3; Strab. 7: fr.10. For the strategic importance of the region see Milivojević 2017, 49-50.

12 Kitchevo. With quoted literature see Proeva - O. Brankoviḱ 2002; Proeva 2014.

${ }^{13}$ Liv. 43.10.; Livy brings a detailed description of the battle. Claudius arrived only 12 miles from the city where he raised a camp. As soon as the night came, he left 1000 troops to guard the camp while he set of with the rest of soldier to attack the city. However, his soldiers reached the city in disarray, and a lot of them were lost because of the night. Claudius was not careful and further encouraged when he saw that on the city walls there were no armed men. Yet, when he reached the city there was a sudden onslaught of enemy through two city gates, while the women and slaves produced colossal noise inside the walls. The Romans were taken by surprise and did not withstood the first wave of enemy attack. More soldiers died during the retreat than in the fighting itself. Only 2000 soldiers, among whom was Claudius, managed to reach the camp. Claudius did not wait for the survivors and took the rest of his army back to Lychnidus. Hammond 1988, 522 brings false information on the amount of soldiers with which Claudius attacked the city. He writes that Claudius attacked Uscana with 12.000 troops and returned to Lychnidus with only 3000 . This is false, since the whole number of his troops in Lychnidus was 8000.

${ }^{14}$ Liv. 43.11. The decision to solve the problem of Macedonia was given to new consuls Quintus Marcius Philippus (II.) and Gnaeus Servilius Caepio. 
After consolidating his army, Claudius waited for the next war season (spring/summer 169 B.C.) to attack Phanote in Epirus. He believed if he took this strong city his name would be cleared of the shameful defeat in Illyricum. This was yet another setback. Claudius had to abandon the siege of Phanote and returned to Lychnidus with heavy losses. ${ }^{15}$ In the meantime, during the same war season (169 B.C.), another Roman commander in Lychnidus, Lucius Coelius tried to reclaim Uscana from the Macedonians (Uscanam retinere), but just as Claudius at Uscana, Caelius retreated to Lychnidus with heavy losses. ${ }^{16}$

So far the general chronology of Roman operations is clear. Sicinius (171 B.C.) sent garrisons to the region where Claudius arrived in 170 B.C. Somewhere in autumn of the same year Claudius was defeated below the walls of Uscana and retreated to Lychnidus with heavy losses. It seems the region north of Lychnidus was in Perseus' control at least until the summer of 169 B.C. when yet another Roman attempt to take Uscana, i.e. Coelius', ended with failure. Claudius' set his mind on operations in Epirus while the fate of Sicinius' garrisons in the forts of the Dassareti and Illyrians remain elusive. However, exactly here lies the main problem.

\section{Problem: Perseus' counterattack}

Claudius' and Coelius' defeat at Uscana clearly indicate that the city was part of Perseus' territory and had a Macedonian garrison precisely from autumn of 170 B.C. to the end of 169 B.C. However, Livy writes that during the winter of 169. B.C Perseus subdued the whole region, including Uscana which had a Roman garrison. ${ }^{17}$ It should be assumed that at a certain point Uscana was conquered by the Romans, and afterwards Macedonias, but for the mentioned period Livy does not give any indications that Rome had certain military successes, while Perseus attacks the city which is obviously no longer within his kingdom. The only documented Roman attempts ended with failure, further confirmed and precisely dated with complementary information. Therefore, the essential problem is how we can fit the story of Perseus' conquering with other Livy's information into one meaningful and constructive story of the events in question.

Livy's description of Perseus' advance is quite important and needs to be presented in detail. Namely, at the outset of winter Perseus did not dare to leave Macedonia fearing the Romans would invade his

${ }^{15}$ Liv. 43.21.4-5. Claudius had a contingent of Chaonians and Thesprotinas who, along with his army, amassed to 6000 soldiers. Yet, Clenas, Perseus' commander in the city had a strong army and managed to repulse Claudius and harassed him almost all the way back to Lychnidus. Meloni 1953, 283; Hammond 1967, 630.

${ }^{16}$ Liv. 43.21. See Milivojević 2017, 52, n. 150.

${ }^{17}$ Liv. 43.18. 
kingdom. However, when the snow blocked the mountain passes from Thessaly he decided to crush the will of his neighbours so he would not have to consider them as a potential danger in spring when the war operations with Rome will continue. There was only one area Perseus intended to secure his kingdom from - the part which allowed access to Macedonia from Illyricum and where the Illyrians were giving the Romans good positions. Perseus also thought if he conquered the nearest Illyrians he would incite Genthius into an alliance with Macedonia. Therefore, with this agenda Perseus set out with 12.000 infantry and 500 cavalry and soon enough reached Stuberra. ${ }^{18}$ From the city he took provisions for couple of days (as well as siege equipment) and in four days' time pitched camp in front of Uscana, where Roman garrison was situated. Perseus immediately started to besiege the city. Although the Romans withstood several attacks (and the winter in the open caused the Macedonians trouble), soon enough Gaius Carvilius from Spoletum and Gaius Afranius were sent to negotiate with Perseus. The terms of their surrender were: the inhabitants, as well as Roman troops will retain their freedom but the city will fall to Perseus. However, Perseus did not honour his promise and after the surrender enslaved everybody. ${ }^{19}$ The majority of prisoners were taken to Stuberra where the Illyrians from Uscana were sold. Roman soldiers (4000 of them) were allocated amongst the various cities as hostages, yet their commanders were deliberately spared. Perseus returned to the region where he put under his control two strategically very important cities - Draudacium and Oaneum. ${ }^{20}$ With mediation of the spared Roman commanders, the Macedonian king received the surrender of 11 oppi$d a$ where additional 1500 Roman troops were situated. Upon comple-

${ }^{18}$ Inscription found at Čepigovo identified it as Roman Stuberra. See Spomenik 71 (1931) no. 501; Meloni 1953, 275; Papazoglu 1953; Oberhummer 1931, col. 395. Hammond 1972, 67-68; Kalpakovska 1999. Macedonian Stuberra should be identified as Bučinsko Kalë on the right bank of the Cerna and in the vicinity of the gorge through which the Cerna enters the plain. See Hammond 1972, 68.

${ }^{19}$ Liv. 43.18.

${ }^{20}$ Livy's description of Oaneum suggest that the city was, on one side, protected by the river Artatus, and on the other by a high and almost impassable mountain (43.18). This description has incited several authors to correctly assume that Oaneum indeed is Tetovo. See Vulić 1934, 28, 39: Mack 1951, 177; Mirdita, 1975, 208-209. Also, the river Artatus must be Vardar (the same oppinion as Vulić 1934, 39), but we should not exclude its branch - Pena, which emerges on Sharr Mountain and flows through Tetovo to Vardar. For different identifications of Artatus see: Tomaschek 1895, 1308 (Radika); Kiepert 1911, XVII (Mat); Tomovski 1962, 342 (Sateska). Further on, Vulić 1934, 28 and 39, proposes a reasonable identification of Gostivar as Draudacium. Mirdita 1975, 211 proposed Gradec near Gostivar as Draudacium. For different identifications of Oaneum and Draudacium see Tomovski 1962; Papazoglu 1957, 66; Sadiku 1971, 251. Livy writes that Marcius, during the meeting, accused Perseus: Arthetauri interfectores, ut caede ne quid ultra dicam, te laetatum appareret, recepisti, quiomnium Illyriorum fidissimus Romanis regulum occiderant, that is, he received in his kingdom the killers of Arthetaurus, the most loyal king of all Illyrians. Also in App. Mac. 11.2. 
tion of his task Perseus sent Pleuratus (the Illyrian) and Adeus (the Macedonian) to Genthius amongst the Labeati to persuade him to declare war on Rome. To achieve this, the envoys were instructed to mention Perseus' successful war operations in summer and winter against the Romans and Dardanians, and his recent winter operations in Illyricum. ${ }^{21}$ Finally, Perseus returned "to the region", strenghtened the garrisons in Uscana and other cities he conquered, and returned to Macedonia. ${ }^{22}$

Considering Livy's information about a Roman garrison stationed in Uscana it is quite justifiable to presume that at a certain point Rome had some successes in the region. Another indication of this is Livy's report on Coelius' defeat at Uscana later in the year (autumn of 169 B.C.). Livy clearly writes the Roman commander tried to retake the city from the Macedonians,$^{23}$ indicating that Uscana was once taken by the Romans but afterwards lost to Perseus. Yet due to the fragmented state of Livy's $43^{\text {rd }}$ book the direct information about the successful Roman attack is probably lost. ${ }^{24}$

Nevertheless, Roman control surely existed at some point. Perseus' counterattack was partially caused by the fact that Roman garrisons were positioned in Uscana and in the broader area of the region. Their existence was a result of a previous Roman advancement in the region, whether by force or additional fortification of allied cities. The question of the exact dating of this Roman control, however, is rather difficult to address because of several chronological problems within Livy's narrative of these events. It also raises additional questions regarding the extent of this Roman control and the possibility of another Macedonian advance in the region, documented only through Perseus' later remark on his victories. In the following paragraphs I will attempt to reconstruct these events with a proposed chronological order of the war operations.

\section{Dating of Perseus' attack}

First of all, it is generally agreed upon that Perseus' counterattack should be placed in the winter of 169 B.C. However, although the prevailing evidence supports the opinion that Livy spoke of the winter at the turn of $170 / 169$ B.C., there are still some authors who believe the attack happened generally in 169 B.C. ${ }^{25}$ This is somewhat understan-

${ }^{21}$ Liv. 43.19.

${ }^{22}$ Liv. 43.20; Identical report on the evoys exists in Polybius, with minor difference in narration of the events. Polyb. 28.8.; Papazoglu 2007, 129-130.

${ }^{23}$ Liv. 43.21. Uscanam retinere.

${ }^{24}$ If it indeed was an attack and Livy mentioned it. Livy's $43^{\text {rd }}$ book is least preserved from all that we have at our disposal while complementary sources are scarce.

${ }^{25}$ Such as Rich 1999, 181 who writes that the attack occurred in the winter of 169 B.C. but without clarifying whether it was the winter at the beginning or the end of the 
dable since there are no arguments in regard to the exact dating of Perseus' attack, Livy's paragraph and its connection to the surrounding text. Further on, without the exact dating of Perseus' attack any further discussion on Livy's text is extremely complicated to follow. Therefore, a somewhat detailed account is needed on the chronology of events preserved in Livy's text.

Basically, there are several problems with dating Perseus' attack. The main one is a lack of complementary information within Livy's paragraph. ${ }^{26}$ The only visible information is the mention of winter operations and fact that this report is placed in a part of Livy's book dealing with 169 B.C. Consequently it could be the winter at the turn of 170/169 B.C., or 169/168 B.C. But without any other indication it is difficult to link these activities to a certain part of the year. In such deficiency the only thing possible is to analyse Livy's text with the goal of determining whether a connection is visible to preceding or succeeding paragraphs where such information might exist.

The succeeding paragraphs are interconnected in a comprehensive story about Coelius' defeat at Uscana and Claudius' expedition in Epirus, ${ }^{27}$ because of which it must be excluded that Perseus' activities should be dated in the winter at the turn of 169/168 B.C. The story revolves around the second half of 169 B.C., and although the narrative does not clearly progress between paragraphs, the truth is that the ending of $43^{\text {rd }}$ book is actually a compilation of information gathered in one place where Livy intended to sporadically mention war operations in Illyricum. Chronologically it is quite justifiable. Perseus' conquest of the region is a part of the story about those operations, and Livy first described the winter activities at the beginning of the year, and then moved on what chronologically follows - summer and autumn operations of Claudius and Coelius. From a historical perspective, considering what is known about Roman-Macedonian conflicts in 169 B.C., it is not only doubtful that Perseus could have undertaken such an attack at the end of the year, ${ }^{28}$ but during the whole second half of

year. This is somewhat understandable since the problems of Perseus' attack and Livy's text are not at the focus of Rich's and similar works.

${ }^{26}$ The mention of a consul or any other magistrate, for whom it would be easy to verify the year of office, would solve the case, yet it is not the case here.

${ }^{27}$ Liv. 43.21-3. The first one has an informative character and gives an introduction to the next two, where Claudius' expedition and Perseus' attack on Stratus in Aetolia is given in detail.

${ }^{28}$ Numerous information from Livy show that Perseus did not have time to deal with the Illyrians. The main cause is that the new consul, Quintus Marcius Philippus, from his arrival in Macedonia (spring 169 B.C.) intensively worked on penetrating Macedonia and ending the war. He disciplined his army, occupied the mountain passes from Thessaly and in one occasion even entered it. Allegedly Perseus in that instance poetically shouted "I am defeated without a battle!". See Liv. 44.16. App. Mac. 15 sets this shout in 171 B.C., yet this is doubtful. The shout must be connected with Marcius' entering Macedonia, because of which Perseus needed to be involved on the southern 
169 B.C. the region was already under Perseus' control. Apart from Coelius' defeat at the hands of Macedonian garrison in Uscana (autumn 169 B.C.) there are other indications. Namely, after finishing the report on Claudius' expedition in Epirus, Livy writes that Perseus sent 1000 infantry and 200 cavalry to Cassandrea, which he demanded from the allied people of Penesti. ${ }^{29}$ This means the region occupied by Penestae was under some form of Macedonian control. The same troops are further mentioned when the Romans finally attacked Cassandrea. Livy's emphasizes the courage of Illyrian Penestae in the final conflicts for the city. ${ }^{30}$ In any case, Perseus' attack must have occurred before all of these events, notably before the summer of 169 B.C.

The only probable dating is in the winter at the turn of $170 / 169$ B.C. There is some indication for this in a paragraph that precedes the description of Perseus' attack. The focus is on a general description of activities at the end of 170 B.C. Roman allies were in a state of political conflict which, if it were to continue, could escalate into a serious problem. That is why the Senate sent envoys to investigate the conditions in Achaea, Aetolia and Acarnania. Upon completion of their task the envoys returned to Larissa, where the proconsul Hostilius was currently staying, while one of them, Popilius, was immediately sent with 1000 troops to winter quarters in Ambracia. ${ }^{31}$ Two reference points are visible from this Livy's report - 1) proconsul Hostilius, 2) winter quarters. Hostilius was a consul of 170 B.C. and his appontment as a proconsul could have lasted only from the end of the year, when his regular mandate expired, until the arrival of a newly elected consul from Rome. Precisely from winter at the turn of 170/169 B.C. to spring in 169 B.C. Marcius' appearance in Macedonia. ${ }^{32}$ Secondly, the mere mention of winter quarters reveals that these activities preceded the actuall start of winter, or they occured at the very beginning of it. Therefore the connection to the paragraph concerning Perseus' upcoming activities is obvious. Livy wrote about proconsul Hostilius' preparations for winter, ended the report, and then described what happened next - Perseus' conquering of the region north of Lake Lychnidus.

\footnotetext{
borders of his kingdom. We find out that with skilled manoeuvres he prevented the further advancement of Roman army. Aemilius Paulus received information at the end of the year that Marcius found himself in a difficult situation, cut off and without options to secure provisions for his army. Liv. 44.20; cf. 44.17-8. This is not unusual for Marcius who was known for a rash commander. See Liv. 39.20. The continuing pressure on Marcius' positions demanded Perseus in Macedonia, and not on distant places where he could not efficiently react on a sudden change of the situation. After all, he was acquainted with the arrival of a new army from Italy, led by Aemilius Paullus. It is highly unlikely Perseus had the time or troops to go and deal with the Illyrians.

${ }^{29}$ Liv. 43.23.

${ }^{30}$ Liv. 44.11.

${ }^{31}$ Liv. 43.17.

${ }^{32}$ Liv. 44.1.
} 
Despite the fragmentary condition of Livy's $43^{\text {rd }}$ book, and the scarcity of complementary information within the description of the attack, it is clear that the preceding and succeeding paragraphs all have a tangible connection to the main story. They clearly follow in a chronological order:

1) Liv. 43. 13 - The beginning of next year (169 B.C.), new consuls were elected.

2) Liv. 43. 14-16 - Description of the elections

3) Liv. 43. 17 - Information about proconsul Hostilius and preparations for winter.

4) Liv. 43. 18-20 - Perseus' attack during winter.

5) Liv. 43. 21-23 - summer and autumn operations of Claudius and Coelius and the end of Livy's $43^{\text {rd }}$ book.

\section{Roman control over Uscana}

There is no doubt when to date Perseus' activities - in the winter at the turn of 170/169 B.C. Consequently, Roman control over Uscana must have occurred before Perseus' attack, that is, during the second part of 170 B.C. There are two reference points when exactly. The first one is the already mentioned argument that it must have happened before Perseus attacked the Roman garrison in the city. The second - we cannot go further back in time than Claudius' defeat by the Macedonian garrison. Thus we are dealing with a timespan from the autumn of 170 B.C. until the winter at the turn of 170/169 B.C. In such a short time Rome must have obtained Uscana and placed a garrison within its walls. Additionally, a point must be made on the method with which Rome subdued Uscana. There are two possibilities - either Rome obtained the city with force, or the people of Uscana changed allegiance.

The first possibility is less acceptable. It must be keep in mind that since there are no indications for existence of another army in Illyricum besides Claudius' (especially in the area around Lychnidus) Uscana would have to be conquered during further Claudius' operations after the initial defeat. This assumption would indicate that Claudius, in short time after the retreat, managed to reorganize his scattered army, gather additional allied troops and launch a second attack on Uscana. In principle this could be done only if several conditions were fulfilled. The main one is the moral of Claudius' army. The defeat at Uscana was no ordinary one, and nothing similar to a pitched battle where one side retreats in order. Roman army was shattered to such an extent that Claudius did not even wait for the wounded soldiers before he retreated to Lychnidus in panic. The moral was undoubtedly at its lowest and if Claudius intended to launch a second attack on Uscana he would have to incite anger or hunger in his soldiers to gain support for 
the attack. Even then he would have to reorganize his army and receive reinforcements in a very short time before the start of the winter. However, there are no indications of any Roman military successes, other than Claudius' failure to capture the city with force. The argument with which the envoys defended Claudius before the Senate did not denote that despite his defeat he managed to launch a second attack and conquer Uscana. The underlying argument was quite opposite - yes, Claudius suffered a heavy defeat but it was not so consequential because only few Italian soldiers fell. ${ }^{33}$ This leads to the assumption that Claudius remained in Lychnidus. He probably wanted to retake Uscana, yet at that moment it was not possible. Even if he could have effectively reorganized his army, the purpose would be to minimize the effects of the defeat and to wait out the winter in Lychnidus with no further losses. There was simply no time or manpower to launch the second attack on Uscana, especially if it is considered that it was a successful one.

The second possibility is most probable - Uscana must have changed allegiance from Macedonia to Rome. ${ }^{34}$ The reasons why Claudius decided to attack the city in the first place indicate such course of action. Claudius received several reports suggesting that if he were to bring his army near the city, the inhabitants would rise against the Macedonian garrison. ${ }^{35}$ In light of his defeat it could be hypothesized that Claudius walked into a trap. ${ }^{36}$ Even Livy criticizes him for not checking the validity of these reports. ${ }^{37}$ However, considering that Uscana received a Roman garrison before Perseus attacked the region, there is a justified probability that the reports were actually true and that the setting of a trap was not deliberately caused by the intentions of the inhabitants, but the unexpected turn of events which followed. The Macedonians could have easily found out about these plans, and decided to lead Claudius into believing that the city would actually surrender, while contemplating the onslaught which would completely shatter his army. In such case the reason for Claudius' defeat would not be in false reports, but in the timely reaction of a Macedonian commander who perfectly seized the opportunity to trap his enemy. Despite Claudius' failure, a pro-Roman sentiment in the city might not have changed, and the existence of Romans in Uscana can be elucidated with the probable events that occurred further on - a smaller contingent of Macedonians was driven out of the city, and for the second time the inhabitants informed Claudius of their intentions to side with Rome.

\footnotetext{
${ }^{33}$ Liv. 43.11.

${ }^{34}$ Opinion shared by Hammond 1988, 523.

${ }^{35}$ Liv. 43.10.

${ }^{36}$ Hammond 1988, 522 believe it is a trap because of the false reports.

${ }^{37}$ Liv. 43.10. Livy writes that Claudius did not demand hostages or retained the
} messengers. 
Claudius clearly responded and sent a garrison to occupy the city - the same garrison which Perseus captured soon afterwards. Although the garrison which he sent was probably a strong one, the number of 4000 captured Romans must be exaggerated. ${ }^{38}$ The loss of almost an entire legion would constitute the biggest defeat the Romans endured not only in this region, but during the whole Third Macedonian War. There is no complementary information which would validate Livy's report, not even on the consequences of the alleged surrender, related events, reactions or reports in Livy or any other source dealing with this period. This is indicative in some way. There is no doubt that the real amount of soldiers sent to Uscana must have been sizeable because of the city's strategic importance and the fact it had a population of 10.000 people, but it is unconstructive to assume Claudius even could have allocated 4000 Roman soldiers from his army. Indeed, his initial force was significant ( 8000 troops, of which 4000 were allies), yet it was considerably decreased after his defeat and retreat to Lychnidus. Claudius found himself in a dangerous situation, significantly complicated by the fact that no Roman reinforcements came to his aid. Allocating 4000 troops from his army would be nearly impossible given his position. ${ }^{39}$

Also, if there were 4000 Roman troops in the city Livy's detailed description of Perseus' attack would be doubtful. Certainly the winter in the open caused the Macedonians trouble, but the force of 12.000 troops with which the king attacked the city would not be a deciding effect for 4000 Romans to surrender. Considering Perseus' forces, such amount of Roman troops could have defended the city for some time and the Macedonians would find themselves in a much different position than Livy describes. One could tell that there indeed were 4000 Romans but their immediate surrender could be caused by shortage of time between the entering of the city and Perseus' attack, in which the Romans did not manage to additionally fortify the city's defences. This could be true, but only if there was a smaller contingent of Roman soldiers in Uscana. We have to keep in mind that Uscana was not destroyed before the Romans entered the city, and that the defences were to a certain extent intact. If Perseus' attacked the city quickly and the defences were not as the Romans could have expected, 4000 troops could have held Perseus outside the walls, and wait until the winter caused the Macedonians additional problems. Livy's description of the attack tells otherwise. It is a description from which one could only assume that the Romans did not expected to hold the defences for a long time. Reasons can exactly be - a smaller amount of

\footnotetext{
${ }^{38}$ Kromayer 1907, 258, ref. 1.

${ }^{39}$ We have to keep in mind that out of the initial 8000 troops Claudius returned to Lychnidus with only 3000 troops (2000 reached the camp where was the additional 1000). Even if we consider that some troops remained in Lychnidus, Livy's report indicate that Claudius lost a lot of men.
} 
soldiers and the already mentioned time in which they did not manage to prepare the city for a siege. The probability is that the exaggerated number of Romans in Uscana is Livy's statistical error which is not unusual for writers who try to describe war operations which happened hundreds of years before their time. ${ }^{40}$ The cautious conclusion would be that Roman control over Uscana occurred immediately after Claudius defeat in autumn of 170 B.C. when a strong detachment of soldiers (less than 4000) was sent to occupy the city.

\section{Claudius takes the region?}

It could be hypothesized that not all of 4000 Roman soldiers in Uscana arrived from Claudius in Lychidus, but from other Roman positions in the region which Perseus conquered later on. This causes yet another problem. In historiography prevails an opinion that at the same time as Uscana several other cities of the region changed allegiance from Macedonia to Rome. ${ }^{41}$ The main argument is Livy's information that Perseus captured Roman garrisons not only in Uscana, but in Draudacim, Oaneum and unknown 11 oppida. However, such conclusion is unsubstantiated. Several reasons suggests otherwise.

Firstly, it must be said that it would be wrong to assume the region had no affiliation towards Macedonia or Rome before and during the war, and that the placement of Roman garrisons occurred only when certain communities decided on their involvement in the Third Macedonian War - meaning that these communities did not have any foreign garrisons and remained neutral until a point when the decision on the engagement became imminent. Considering the strategic importance of the region, this cannot be true. Situated at the border area of Illyrian Kingdom, Perseus' territory and Roman protectorate, the communities inhabiting the region did not have any choice other than to be included in the conflicts. Possibly the only thing they could have done is at a certain point decide on which side to align, hopefully choosing the one which had the most chances of winning the war. Undoubtedly the garrisons of either Perseus or Rome existed within their walls. The question is which ones and when to date them.

This is not an easy task. The fact that Roman garrisons were situated along the region is a clear proof of Roman advancement, but if were to assume that they were placed immediately after Claudius' defeat we would have to rely on the possibility that Claudius could have secured the region, and that it was initially Macedonian before joining the Roman side, as Hammond would have it. This would mean that Rome (i.e. Claudius) acquired these positions at the same time when the securing of Uscana occurred. As already said, Claudius did not have

${ }^{40}$ Either Livy did not check the validity of recieved information, or the confusion is caused by his usage of, in this case, probably a pro-Macedonian Greek author.

${ }^{41}$ Hammond 1988, 524. 
enough time or troops for the second attack, and the furthest extent of his capabilities was to send a smaller garrison to Uscana. With the situation at hand, assumption that despite the defeat, casualties and the proximity of winter Claudius could have sent additional troops to secure 13 positions cannot represent a logical turn of events, even if these troops were only garrisons, responding to a pro-Roman sentiment and the general expulsion of Macedonian troops from the region. There is no doubt that the positioning of Romans happened, but it is doubtful it must be dated immediately after Claudius' defeat. These actions required troops and time in which the extensive securing of the region was possible, none of which Claudius had at his disposal. There is no scenario in which Claudius could have efficiently secured Uscana and the rest of the region in such a short time, and without reinforcements.

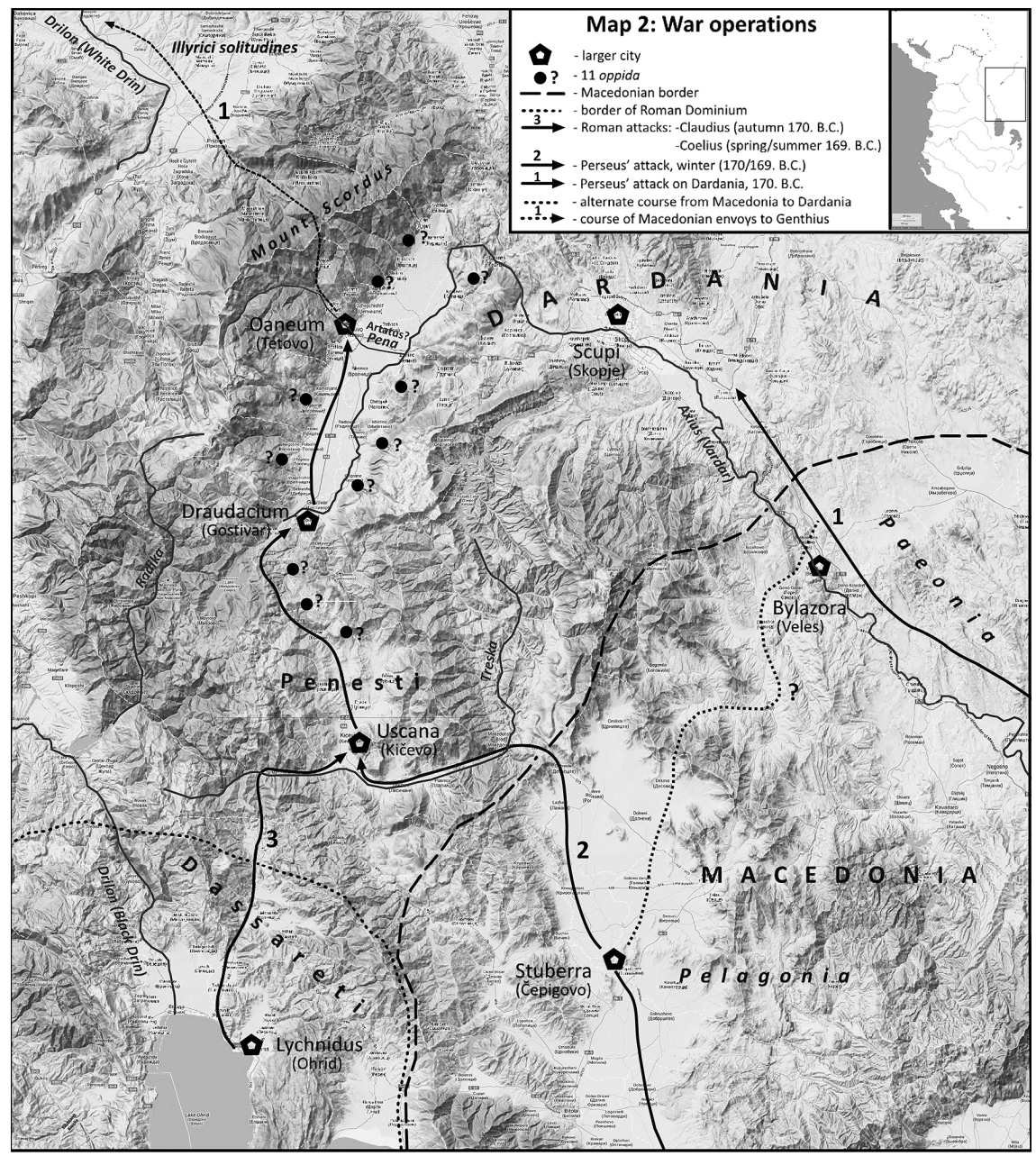

Map 2. War operations in the region north of Lake Lychnidus 
Therefore, when should we date the placement of these garrisons? Since there are several information that the region remained Macedonian from Perseus' conquer until the end of the Third Macedonian War, ${ }^{42}$ the only possible conclusion is that Roman advancement in the region must be dated before Claudius arrived in Lychnidus (autumn of 170 B.C.). There is only one indication of Roman successes in obtaining these positions before Claudius - precisely the activities of Gnaeus Sicinius. As already explained, Sicinius sent 2000 troops to occupy the forts of the Dassareti and Illyrians somewhere during 171 B.C. Although we do not have any direct confirmation that Sicinius' garrisons are actually the garrisons which Perseus captured, the nature of Sicinius' order and his intentions are clearly connected to what Perseus was trying to accomplish with his attack - securing of this very important region. Undertaking of such magnitude could not be successfully carried unless garrisons were placed in Uscana, Oaneum, Draudacium and 11 oppida. Otherwise, Sicinius would not threaten Perseus' position in the war and would not secure the region, which was the main goal. He was the only Roman commander (that we know of) who had the manpower and ability to put such plan in action. Even if in the lost transcripts of Livy, Polybius and other sources dealing with this period there existed information on reinforcements or additional commanders which came to this region after Sicinius and before Claudius, the general idea does not change. From Sicinius' actions in 171 B.C. several garrisons remained in the region until Perseus decided to attack them with a formidable force in the winter at the turn of 170/169 B.C. and once for all resolve this situation to his advantage.

\section{Previous Perseus' attack on Uscana (170 B.C.)}

However, this theory does not explain the fact that a Macedonian garrison defeated Claudius in autumn of 170 B.C. More specifically, if Sicinius' secured the region with Uscana as its most important city, and Perseus finally conquered it in the winter at the beginning of 169 B.C., how is it possible that Uscana had a Macedonian garrison precisely in autumn of 170 B.C.? The most probable solution is that Perseus conquered Uscana even before Claudius came to Lychnidus. We even have an indication when this might have occurred: Livy's remark on Perseus' attack on the Dardanians. ${ }^{43}$

In the closing part of Livy's narrative on Perseus' counterattack on Roman positions in the region we find out that the Macedonian king sent envoys to king Genthius with instructions to mention, among other things, Perseus' operations in summer and winter against the Romans and Dardanians. Unfortunately, a part of Livy's $43^{\text {rd }}$ book that deals with these operations in detail is lost, and the only indication

\footnotetext{
${ }^{42}$ Liv. 43.23, 44.11.

${ }^{43}$ Liv. 43.19.
} 
they even occurred is in the instructions the envoys received before departing to Illyrian court. ${ }^{44}$ Nevertheless, despite the lost information, there is a somewhat consensus in modern historiography that Livy described the events during the war season of 170 B.C. ${ }^{45}$ Considering the dating and that the nominal territory of the Dardanians was rather close to those of the Penesti and other Illyrians, ${ }^{46}$ there is a real possibility that Perseus' operations also included the securing of Uscana. This would mean that between 170 and 169 B.C. Uscana was occupied at least four different times:

1) 171 B.C. - Sicinius' sends a garrison to Uscana

2) 170 B.C. - Perseus' takes Uscana during the attack on the Dardanians

3) 170/169 B.C. - Claudius managed to use the pro-Roman sentiment in Uscana and placed a smaller garrison.

4) 169 B.C. - Perseus finally conquered the region with Uscana as the most important city.

Basically, the explanation of this course of events really depends on what was Perseus trying to accomplish with his attack on the Dardanians. It is well known that the antagonism between the Macedonians and Dardanians lasted well on in history and certainly long before the start of the Third Macedonian War. Wars were fought because the territorial boundaries between these two entities crossed very difficult terrain which included several important positions. ${ }^{47} \mathrm{Clear}-$ ly, in every situation where the Macedonians were involved in a war against a foreign foe, a real concern existed what to do with their northern enemies. Dardanians were dangerous, close to Macedonian positions and Perseus needed to deal with them before significant Roman troops were to advance through Thessaly and engage his forces. This was a problem that needed to be resolved, otherwise Perseus would leave his north-western borders unprotected approximately few months after Sicinius' securing of the region north of Lake Lychnidus. Therefore, Perseus intended to secure his borders in the same way he did in the winter at the turn of 170/169 B.C.

However, there is no need to assume that Perseus intended to attack the Polog valley and thus resolve his problems with the Dardanians. ${ }^{48}$ With no doubt it was an area which was important from a strategic point of view (because the enemy could have entered western Macedonia via Popovec-Kičevo-Prilep) and Perseus probably knew that

\footnotetext{
${ }^{44}$ There is an indication in Plut. Aem. 9.

${ }^{45}$ Hammond and Walbank 1988, 521. Papazoglu 2007, 130. For Diodorus 30.4 see Papazoglu 1969, 129, ref. 127.

${ }^{46}$ See Mirdita 1999-2000.

${ }^{47}$ Such as Bylazora, Scupi. See Hammond 1988, 385-386.

${ }^{48}$ Hammond 1988, 523 believes the Polog valley was Dardanian and that Perseus conquered it probably in 170 B.C.
} 
at some point he would have to launch an offensive in that direction. But Perseus also probably knew that he did not have to actually hold the Polog valley to secure his kingdom. What he needed to do is control the entrances to his kingdom, that is, defend those positions from where the Dardanians (and other enemies) could have more easily invaded Macedonia. As for the Dardanians, that area was precisely the northern borders of Macedonia, around the river Axius (Vardar) which connected Skopje-Veles valleys, and the cities Scupi-Bylazora. Probably the most important city of the region was Bylazora in Paeonia (hillfort over modern Knezhje) which, as Walbank discloses, commanded the pass over into Dardania. ${ }^{49}$ In the context of a possible Dardanian threat the city (Bylazora) and region (Paeonia) were extremely important to Perseus, mainly because if Bylazora fell, Paeonia would be next and the Dardanians would then have a clear way of advancing to the heart of Macedonia. This would put Perseus in a very difficult position. ${ }^{50}$ Therefore, in all probability, Livy's fragmentary information about Perseus' attack on the Dardanians must be connected to the intentions of the Macedonian king to secure the area around Bylazora and Skopje valley, rather than Polog valley.

Livy's information indicate that Perseus' attack on the Dardanians was a success, but if the plan was to secure the north-western entrances to Macedonia, Perseus also needed to control Uscana. The city controlled three important communications: 1) towards western Macedonia (via Makedonski Brod-Prilep); 2) to the north-west and the slopes of Sharr Mountain (via Gostivar-Tetovo); 3 ) and to the entrance to the Roman Protectorate around Lake Lychnidus (via Popoec-PesočaniStruga-Ohrid). This made Uscana simply too important not to control, especially if we take into account Sicinius' garrisons in the region north of Lake Lychnidus. Perseus needed to respond and protect the western entrance to his kingdom. This could only be done by taking Uscana ${ }^{51}$ We do not direct information when this happened, but if there was a Macedonian garrison in the city and it must have been placed after Sicinius' activities and before Claudius' arrival Lychnidus, the operations against the Dardanians are the only probable choice. This would correspond to Perseus' general idea to secure his north-western borders. Sicinius threatened Perseus' control over western Macedonia and Perseus secured Uscana with a Macedonian garrison, while the usual threat from the Dardanians was resolved by attacking their positions and strengthening Bylazora.

Such a turn of events would indeed explain why Claudius was sent to Illyricum in the first place. Sicinius' decision to send 2000 troops

\footnotetext{
${ }^{49}$ Walbank 1940, 63. Hammond 1972, 80-81.

${ }^{50}$ Especially during 170 B.C. when considerable amount of his forces were engaged in the conflicts against the Romans in Thessaly.

${ }^{51}$ Also, by taking Uscana Perseus would create the first line of defence before the moment presented itself for an attack on Roman positions.
} 
to the Dassareti and Illyrians resulted in the securing of positions along the region north of Lake Lychnidus. Among these positions were formidable cities such as Lychnidus, Uscana, Draudacium and Oaneum. Yet, during Perseus' attack on the Dardanians, Uscana fell to the Macedonians, and a small detachment of Cretan soldiers further on protected the entrance to western Macedonia. Rome possibly saw this as a threat and consul Hostilius sent Claudius to Illyricum either to obtain the city back, or to stay in Lychnidus as a precautionary measure in case the fall of Uscana predicted a larger Perseus' attack on Roman positions. The rest is clear-Claudius failed, but the pro-Roman sentiment in the city did not change. The Macedonians were driven out of the city and these turn of events demonstrated to Perseus that the danger to his borders were not only in the area around Skopje valley, and in the winter at the turn of 170/169 Perseus decided to resolve his problems with a massive attack. Roman garrisons were captured and the region remained under Macedonian control until the end of the Third Macedonian War. ${ }^{52}$

\section{Conclusion}

Considering the amount of information presented in this article, a detailed conclusion is necessary. It will serve as a simplified explanation of the analysis presented in article, as well as a chronological list of operations in the region north of Lake Lychnidus during the Third Macedonian War.

As soon as the hostilities in the Third Macedonian War were declared, in 172 B.C. the Senate decided to send praetor Gnaeus Sicinius with a formidable force to Epirus. His task was to secure the coastal area of Roman protectorate where the consul, to whom Macedonia will be allotted, will soon disembark with his own army. Upon arrival in Epirus (171 B.C.), Sicinius raised a camp in Nymphaeum, in the vicinity of Apollonia, and sent tribunes with 2000 troops to secure the forts of Dassareti and Illyrians, peoples who asked for Rome's help. Those forts were situated in a strategically very important region, precisely from Lake Lychnidus to Polog valley in the north and the slopes of Sharr Mountain.

The reasons why Sicinius decided to send 2000 troops to the forts of Dassareti and Illyrians are clear. ${ }^{53}$ By securing the region north of Lake Lychnidus Rome would complicate any communication

52 The last information on Appius Claudius is already mentioned report from the envoys of Aemilius Paullus. Claudius reported that he could not do anything of worth to endanger Perseus, because he did not have enough troops and was withour reinforcements. Soon enough he was replaced with L. Anicius at the outset of the Third Illyrian War. Liv. 44.20.

${ }^{53}$ Milivojević 2017, 48 ff. 
between Perseus and Genthius, the Illyrian king. ${ }^{54}$ This was necessary because the Senate was extremely suspicious of Genthius. Several reports indicated that he will not join the Roman cause in upcoming conflicts and Rome needed to react. If Genthius aligned with Perseus, Roman army would find itself between two combined enemies for the first time on the Eastern shores of the Adriatic. With positioning of troops in the region north of Lake Lychnidus Rome would at least create the first line of defence, and in the case of Perseus' attack those troops would hold the enemy until the arrival of considerable reinforcements. Lastly, the region just north of Lake Lychnidus had dominant positions, such as Uscana which controlled passages into Western Macedonia, towards the Polog valley and also to the valley of river Genusus (Skhumbin). ${ }^{55}$ Therefore, Sicinius positioned troops in major cities such as Lychnidus, Uscana, Draudacium, Oaneum and for the time being complicated any communication between kings, secured the borders and opened a possibility of invading Western Macedonia.

However, Perseus did not stand idle. Livy brings one isolated information on Perseus' attack against the Dardanians on the northern borders of his kingdom. Although a part of Livy's $43^{\text {rd }}$ book that deals with these operations is lost, Perseus obviously intended to secure his borders during 170 B.C. before Roman troops were to again advance through Thessaly and engage his forces. Considering the purpose of his attack, it is clear that it happened somewhere along the river Axius (Vardar), which connected the Skopje and Veles valleys and where Bylazora was situated, a Macedonian city that commanded the pass to Dardania. The attack was successful and Perseus managed to eliminate the threat from the Dardanians, yet the preceding positioning of Romans along the region north of Lake Lychnidus proved as an additional threat. Although we do not know exactly when it happened, Perseus clearly responded to Roman advancement and sometime during his attack on the Dardanians obtained Uscana, the most important city of the region north of Lake Lychnidus. Perseus placed a small detachment of Cretan soldiers in Uscana that further on protected the entrance to the western parts of Macedonia. What is more, by controlling Uscana Perseus managed to isolate Roman troops in Polog valley from the ones in Lychnidus (See Map 2). Uscana served Perseus as the first line of defence of western Macedonia and as a starting point for further conquest, when the opportunity presents itself.

There is no doubt the placement of a Macedonian garrison in Uscana alarmed the Romans. The Senate thought it needed to act and instructed Aulus Hostilius Mancinus, Roman consul in Thessaly, to send Appius Claudius Centho in Illyricum to protect the bordering peoples. For this task Claudius received 4000 troops, but during his

${ }^{54}$ Also Hammond 1988, 523.

55 The valley of Genusus went all the way up to the coastal area around Dyrrhachium and Apollonia which was important to Rome. Milivojević 2017, 49. 
march to Illyricum Claudius increased the amount of his forces to 8000 and after traversing the whole region he occupied the position in Lychnidus among the Dassareti. In essence, Claudius was sent to Illyricum as a precautionary measure in case the fall of Uscana predicted a larger Perseus' attack on Roman positions. Incited by the reports on the intention of the population of Uscana to rise against Perseus if he were to draw his army near, Claudius decided to retake Uscana from the Macedonians in autumn of 170 B.C. Yet the attack was a complete disaster. Claudius was severely defeated and managed to retreat to Lychnidus with only 2000 wounded soldiers. The winter has already started and Claudius found himself in a very difficult position.

The news of Claudius' defeat reached the Senate through a military tribune Sextus Digitus. The Senate was alarmed and sent Marcus Fulvius Flaccuss and Marcus Caninius Rebilus to investigate what exactly happened at Uscana. Although the envoys reported that Claudius' defeat was not so severe, because among the fallen soldiers most of them were allies, the Senate was not pleased. Conditions in which Claudius found himself were far from favourable. However, despite the defeat, the pro-Roman sentiment of Uscana's population turned out to be genuine. Shortly after Claudius' retreat, Uscana changed allegiance and Claudius responded by sending a strong detachment of soldiers as garrison. Uscana was once more under Roman control.

Just as the Romans were alarmed by Perseus' taking of Uscana, the Macedonian king was alarmed by the expulsion of his garrison and Perseus decided to finally resolve the problem of Uscana and western borders of Macedonia. Livy extensively writes about this attack.

Namely, after Uscana fell to the Romans, Perseus, during the same winter at the turn of 170/169 B.C., immediately advanced with 12.000 troops and 500 cavalry, and in short time reached Uscana's walls. Even though the winter in the open caused him problems, soon Caius Carvilius from Spoletum and Caius Afranius from the Roman garrison in the city began negotiations for surrender. Although the agreement was beneficial to the Romans, Perseus broke his promise and enslaved everybody from the city, while the Roman commanders were spared. Perseus further advanced to Polog valley where he conquered Draudacium, Oaneum, and with mediation of the Roman commanders managed to receive surrender from 11 oppida in the region, where 1500 Roman troops were situated. Perseus conquered the whole region with this attack, expelled the Romans and thought that the time has come to involve Genthius in his war with Rome. Envoys were sent and the negotiations with the Illyrian king commenced.

Further events illuminate the inability of the Romans to once more obtain the region north of Lake Lychnidus and turn the initiative in the war to their advantage. Claudius was still the leading commander of Roman forces in Lychnidus, yet the shame of the defeat at Uscana 
troubled him. That is why in the next war season, spring/summer of 169 B.C., Claudius decided to attack Phanote in Epirus. He believed that by taking this strong city he would clear his name of the shameful defeat in Illyricum. The whole episode ended with another defeat. Clenas, Perseus' commander in the city, broke of the siege and pressed against Claudius' line until there was nothing left for him to do than retreat to Illyricum at the beginning of winter. In the meantime, Lucius Coelius, in Claudius' absence the leading commander in Lychnidus, launched a second attack on Uscana in autumn of 169 B.C. However, just as Claudius, Coelius did not succeed in obtaining the city. The Macedonian garrison repulsed the attack and Coelius had to retreat to Lychnidus at the beginning of winter with substantial amount of wounded soldiers. Both commanders, Claudius and Coelius, returned to their original area of operations in Lychnidus, and welcomed the ending of 169 B.C. defeated and without reinforcements.

The region north of Lake Lychnidus remained under Perseus' control until the end of the Third Macedonian War. When the eventual victor over Perseus in the war, Lucius Aemilius Paullus, sent envoys to Roman armies across the Adriatic, Claudius reported that he did not have enough troops or reinforcements to endanger Perseus' position in his area of operations. ${ }^{56}$ This was indicative of all Roman attempts in the region. Claudius' army was in danger and needed help. Eventually the Senate recognized the problem and immediately replaced Claudius with Lucius Anicius Gallus, a commander who went on from being a designated commander of the forces in Lychnidus to be remembered in history as the Roman who defeated Genthius in the Third Illyrian War. ${ }^{57}$

\section{BIBLIOGRAPHY}

Briscoe, J. A Commentary on Livy, Books 41-45, Oxford-New York, 2012.

Broughton, T. R. S. The Magistrates of the Roman Republic, Vol. I., 509 B.C-100. B.C., New York, 1951.

Derow, P. "Rome, the fall of Macedon and the sack of Corinth", in: The Cambridge Ancient History, Vol. VIII: Rome and the Mediterranean to 133 BC, A. E. Astin, F. W. Walbank, M. W. Frederiksen, R. M. Ogilvie (eds.), Cambridge, 1989, 290-324.

Gruen, E. S. The Hellenistic world and the coming of Rome, Vol. I \& II., Berkeley and Los Angeles, 1984.

Hammond, N. G. L. "The kingdoms in Illyria circa 400-167 B.C.”, Collected Studies, II (1993), 239-253.

Hammond, N. G. L. "Part three", in: N. G. L. Hammond and F. W. Walbank, A History of Macedonia, Vol. III., 336 - 167 B.C., Oxford, 1988, 367-571.

${ }^{56}$ Liv. 44.20.5.

${ }^{57}$ Liv. 44.21, 44.30.10-15. 
Hammond, N. G. L. A History of Macedonia, Vol. I., Historical geography and prehistory, Oxford, 1972.

Hammond, N. G. L. "Illyris, Rome and Macedon in 229-205. B.C.", Journal of Roman Studies, 56.1-2 (1968), 1-21.

Hammond, N. G. L. Epirus, Oxford, 1967.

Kalpakovska, V. "Styberra in the Roman period", Živa antika 49 (1999), 155-171.

Kiepert, H. Formae orbis antiqui: usque ad Traianum et Hadrianum, Imperium Romanum, Vol. 33, Berolini, 1911.

Kromayer, J. Antike Schlachtfeder in Griechenland, Bd. II, Die Hellenistich-Römische periode, von Kynoskephalae bis Pharsalos, Berlin, 1907.

Luce, T. J. Livy. The Composition of His History, Princeton, 1977.

Mack, R. Grenzmarken und Nachbaren Makedoniens im Norden und Westen, $\mathrm{PhD}$ thesis, Gottingen, 1951.

Meloni, P. Perseo e la fine della monarchia Macedone, Roma, 1953.

Milivojević, F. Cezarov Ilirik, PhD thesis, Zadar, 2017.

Mirdita, Z. O južnoj granici Dardanaca i Dardanije u Antici, Vjesnik arheološkog muzeja u Zagrebu, 3.32-33 (1999-2000), 63-92.

Mirdita, Z. "Intorno al problema dell'ubicazione e della identificazione di alcuni agglomerati Dardani nel tempo preromano", in: Utvrđena ilirska naselja, A. Benac (ed.), Mostar, 1975, 201-216.

Oberhummer, E. "Stuberra", Pauly-Wissova-Kroll-Mittelhaus-Ziegler, Real-Encyclopädie der classischen Altertumswissenschaft, R. 7, Bd. IV, A. 1, Stoa-Symposion, col. 395, Stuttgart, 1931.

Papazoglu, F. Srednjobalkanska plemena u predrimsko doba: Tribali, Autarijati, Dardanci, Skordisci i Mezi, Beograd, 2007.

Papazoglu, F. Makedonski gradovi u rimsko doba, Skopje, 1957.

Papazoglu, F. "Jedan nov natpis iz Čepigova”, Živa antika 3 (1953), 216-221.

Proeva, N. "Sur les tribus dassarètes (Penestae, Dasaretae, Engeleanes) et la localisation de la ville d'Uscana en Haute Dessarétie", Živa Antika 64 (2014), 165-183.

Proeva, N., Brankovik, O. "Le problème de localisation de la ville d'Uscana en haute Dassarétie”, in:, L'Illyrie méridionale et l'Épire dans l'Antiquité 4 (2002), P. Cabanes - J.L. Lamboley J.-L. (eds.), 197-202.

Rich, J. P. The logistics of the Roman army at war (264 B.C. - 235 A.D), Leiden-BostonKöln, 1999.

Sadiku, H. "Essai d'identification des forteresses et citis illyriennes des Penestes", in: Les Illyriens et la genèse des Albanais, Travaux de la session du 3-4 mars 1969., M. Korkuti, Anamali Skënder, Gjinari Jorgji, Luka Kolë (eds.), Tirana, 1971, 251-252.

Tomaschek, W. “Artatus”, Pauly-Wissova-Kroll-Mittelhaus-Ziegler, Real-Encyclopädie der classischen Altertumswissenschaft, Bd. II, Hb. 1, Apollon-Artemis, col. 1308, Stuttgart, 1895.

Tomovski, T. "Auf den Spuren der illyrischen Siedlungen Uscana”, Živa antika 12 (1962), 340-343.

Vulić, N. "Ratovanje makedonskog kralja Perseja s Rimljanima u našoj zemlji 170 i 169. god. pre Hr. ", Glas srpske kraljevske akademija, 160.82 (1934), 40-53.

Walbank, F. W. "Southern Illyria in the Third and Second centuries B.C. ", Iliria, 4 (1972), 265-272.

Walbank, F. W. Philip V. of Macedon, Cambridge, 1940.

Walbank, F. W. “A note on the embassy of Q. Marcius Philippus 172. B.C.”, Journal of Roman studies, 31.1-2 (1941), 82-93.

Warrior, V. M. Livy, "Book 42: Structure and Chronology", American Journal of Ancient History, 6 (1981), 1-50. 
